Następnie pracownicy Katedry Prawa Europejskiego będący redaktorami księgi pamiątkowej wręczyli księgę Jubilatowi - księga ta jest wyrazem podziękowania za opiekę w trakcie pracy naukowej, jak również podkreśla wieloletnie dokonania Profesora na polu nauki prawa i dydaktyki akademickiej. Księga pamiątkowa Profesora Mariana Kępińskiego, zatytułowana Problemy polskiego i europejskiego prawa prywatnego, jest hołdem dla pracy Profesora, a jej treść i zawarte w niej opracowania dotyczą tych wielu dziedzin, na których koncentrowała się Jego działalność naukowa i publicystyczna ${ }^{2}$. Księga zawiera publikacje naukowe 30 autorów i składa się z 4 części i liczy 579 stron. W pierwszej części ukazana została sylwetka Profesora Kępińskiego i jego dorobek naukowy od 1969 r. (w postaci bibliografii liczącej 268 pozycji). W drugiej części zawarto opracowania naukowe $\mathrm{z}$ dziedzin prawa cywilnego, handlowego i prawa prywatnego międzynarodowego, w trzeciej opracowania z zakresu prawa własności intelektualnej i ochrony konkurencji (w tym także opracowania w języku niemieckim i angielskim), a czwarta obejmuje opracowania z dziedziny prawa Unii Europejskiej, varia, a także wykaz skrótów oraz spis autorów. Po wręczeniu księgi pamiątkowej głos zabrał sam Jubilat, który w wieńczącym uroczystość przemówieniu przedstawił swój życiorys osobisty i zawodowy. Później nastąpiła część artystyczną obejmująca koncert duetu Maria Liszkowska-Sikorska - wiolonczela oraz Małgorzata Sajna-Mataczyńska - fortepian, który wykonał utwory: L. Boccherini - Menuet z XIII kwintetu smyczkowego, F. Mendelssohn-Bartholdy - Pieśń wiosenna, C. Saint-Saens - Łabędź z Karnawatu zwierzat, A. Rubinstein - Melodia, E. Granados - Andaluza z Danzas españolas, A. Piazzola - Adios nonino.

Na zakończenie oficjalnej części uroczystości Profesor Kępiński podziękował wszystkim osobom, które wzięły w niej udział, i wraz z nimi udał się do Sali Lustrzanej w holu Auli Uniwersyteckiej, gdzie na wszystkich gości oczekiwał okolicznościowy poczęstunek. Tam w miłej i ciepłej atmosferze Jubilat odbierał serdeczne i przepełnione uznaniem gratulacje.

Marcin Sokołowski

${ }^{2}$ Problemy polskiego $i$ europejskiego prawa prywatnego. Ksiega pamiatkowa Profesora Mariana Kepińskiego, red. K. Klafkowska-Waśniowska, M. Mataczyński. R. Sikorski, M. Sokołowski, Wolters Kluwer, Warszawa 2012.

\title{
AKTUALNE PROBLEMY POSTĘPOWANIA EGZEKUCYJNEGO W ADMINISTRACJI MIEDZYNARODOWA KONFERENCJA NAUKOWA \\ Poznań, 9 listopada 2012 r.
}

Międzynarodowa Konferencja Naukowa, poświęcona ocenie obecnego stanu prawnego polskiego postępowania egzekucyjnego $\mathrm{w}$ administracji ${ }^{1} \mathrm{z}$ punktu widzenia teoretycznoprawnego, prawnoporównawczego oraz praktyki orzecznictwa sądów administracyjnych i powszechnych, została zorganizowana przez Wojewódzki Sąd Administracyjny w Poznaniu we współpracy z Katedrą Postępowania Administracyjnego Uniwersytetu im. Adama Mickiewicza. Honorowy patronat nad jej przebiegiem objęli Prezes Naczelnego Sądu Administracyjnego prof. dr hab. Roman Hauser oraz Dziekan Wydziału Prawa i Administracji prof. dr hab. Roman Budzinowski. Obrady odbywały się w siedzibie WSA i wzięli w nich udział przedstawiciele polskiej i niemieckiej nauki oraz praktyki stosowania prawa postępowania administracyjnego.

${ }^{1}$ Ustawa z 17 czerwca 1966 r. o postępowaniu egzekucyjnym w administracji, t.jedn.: Dz. U. 2012, poz. 1-15 ze zm. (dalej jako: u.p.e.a.). 
Konferencja rozpoczęła się powitaniem przybyłych uczestników przez Prezesa WSA w Poznaniu, sędziego Jerzego Stankowskiego. Na trafność zestawienia ze sobą dwóch porządków prawnych postępowania egzekucyjnego $\mathrm{w}$ administracji - polskiego oraz niemieckiego - zwrócił uwagę na samym początku prowadzący obrady prof. dr hab. Andrzej Skoczylas (UAM), wskazując, że regulacja prawna międzywojennego polskiego postępowania przymusowego $\mathrm{w}$ administracji ${ }^{2}$ opierała się w znacznym zakresie na wzorcu w postaci niemieckiej ustawy egzekucyjnej. Przebieg konferencji ukazał jednak obok podobieństw również odmienności w obu systemach prawnych.

Pierwsza z dwóch sesji konferencyjnych poświęcona została zagadnieniom przebiegu postępowania egzekucyjnego $\mathrm{w}$ administracji. W referacie rozpoczynającym obrady dr Krzysztof Sobieralski (UWr i SKO we Wrocławiu) przedstawił problematykę stosowania przepisów procedury administracyjnej w postępowaniu egzekucyjnym w administracji. Prowadząc rozważania z punktu widzenia kontroli sądowej sprawowanej przez polskie sądy administracyjne nad przebiegiem postępowania egzekucyjnego, prelegent zwrócił uwagę na trudność związaną z różnorakim pojmowaniem odpowiedniego stosowania przepisów prawa, które w konkretnej sytuacji prawnej może oznaczać stosowanie Kodeksu postępowania administracyjnego ${ }^{3}$ wprost do drugiego zakresu odniesienia, stosowanie ze zmianami albo zupełne wyłączenie możliwości odpowiedniego stosowania k.p.a. do przebiegu postępowania egzekucyjnego. Zdaniem dr Sobieralskiego wprost w postępowaniu egzekucyjnym stosowane są instytucyjne procesu administracyjnego o charakterze technicznym (takie jak przepisy o doręczeniach oraz protokołach). Szereg wątpliwości budzi natomiast możliwość odpowiedniego stosowania przepisów postępowania administracyjnego dotyczących trybów nadzwyczajnych uregulowanych w k.p.a., pełnomocnictwa (w tym również tzw. pełnomocnictwa administracyjnego, o którym stanowi art. 268a k.p.a.), zawieszenia postępowania, udziału w postępowaniu egzekucyjnym organizacji społecznej. Problematyka odpowiedniego stosowania k.p.a. w postępowaniu egzekucyjnym w administracji odnosi się również do zasad ogólnych k.p.a. i dopuszczalności ich transponowania do drugiego zakresu odniesienia, którym jest u.p.e.a. Zdaniem K. Sobieralskiego, nie wszystkie zasady ogólne jurysdykcyjnego postępowania administracyjnego znajduja zastosowanie $\mathrm{w}$ postępowaniu egzekucyjnym $\mathrm{z}$ uwagi na jego charakter. Zastosowania nie znajduje $\mathrm{w}$ obszarze postępowania egzekucyjnego zasada ugodowego załatwiania spraw, o której stanowi art. 13 § 1-2 k.p.a. Dlatego według prelegenta art. 18 u.p.e.a. to klasyczna norma dopełnienia, która nie może być stosowana w sposób mechaniczny oraz nieprzemyślany. W zakończeniu referatu dr Sobieralski zwrócił uwagę na konieczność każdorazowego uwzględnienia specyfiki u.p.e.a., która niejednokrotnie jest przesadzającym kryterium możliwości zastosowania k.p.a. do postępowania egzekucyjnego w administracji.

Problematyce ustanowienia środka przymusu zgodnie z $\S 14$ federalnej ustawy o egzekucji administracyjnej ${ }^{4} \mathrm{i}$ odpowiednich przepisów ustaw o egzekucji administracyjnej krajów związkowych $\mathrm{w}$ orzecznictwie sądów administracyjnych poświęcony był referat dr. Axela Schreiera (sędzia Oberverwaltungsgericht $\mathrm{w}$ Berlinie). Przedstawiając wskazany powyżej temat, prelegent poświęcił istotną uwagę konstrukcji prawnej niemieckiego postępowania egzekucyjnego. Zastosowanie jednego z trzech środków przymusu, którymi są grzywna w celu przymuszenia, wykonanie zastępcze oraz przymus bezpośredni, musi zostać poprzedzone stwierdzeniem przez organ egzekucyjny wydania aktu administracyjnego nadającego się do egzekucji oraz wystosowaniem do zobowiązanego pisemnego upomnienia $\mathrm{z}$ zagrożeniem zastosowania jednego $\mathrm{z}$ wymienionych środków przymusu. Użycie któregokolwiek ze środków przymusu stanowi ostateczny sposób wykonania nałożonego w akcie administracyjnym obowiązku. Jednocześnie służy ono zachowaniu pewności obrotu prawnego oraz efektywności działania administracji publicznej. O rodzaju możliwego do zastosowania środka przymusu oraz terminie, w którym dopuszczalne jest jego użycie, zobowiązany powinien zostać poinformowany w pisemnym upomnieniu. Do przytoczonego w opisanym referacie ogólnego zarysu przebiegu niemieckiego federalnego postępowania egzekucyjnego nawiązywali dwaj kolejni prelegenci z Niemiec: prof. dr dr h.c. Franz-Joseph Peine oraz sędzia Dirck Maresch.

${ }^{2}$ Rozporządzenie Prezydenta RP z 22 marca 1928 r. o postępowaniu przymusowem w administracji, Dz. U. 1928, Nr 36, poz. 342.

${ }^{3}$ Ustawa z 14 czerwca 1960 r. - Kodeks postępowania administracyjnego, t.jedn.: Dz. U. 2000, Nr 98, poz. 1071 ze zm.

${ }^{4}$ Ustawa z 27 kwietnia 1953 r. Verwaltungs-Vollstreckungsgesetz, BGB1. I S. 157 (dalej jako: VwVG). 
W ramach pierwszej sesji konferencyjnej teoretycznoprawne aspekty przebiegu postępowania egzekucyjnego przedstawił prof. dr hab. Wojciech Jakimowicz (UJ i sędzia WSA w Krakowie). Poruszył on problem kreślenia obowiązku w tytule wykonawczym. Prelegent, koncentrując się na obowiązkach publicznoprawnych wynikających z decyzji administracyjnych, zwrócił uwagę na niezbędność prawidłowego sformułowania obowiązku w tytule wykonawczym (zgodnie z art. $27 \S 1$ pkt 3 u.p.e.a.), które powinno być w maksymalny możliwie sposób precyzyjne oraz jednoznaczne. Stwierdzenie to, jako niebudzące wątpliwości, nie przekłada się jednak na praktykę stosowania prawa administracyjnego. Następnie referent przedstawił relację zachodzącą pomiędzy jednostką a wspólnotą państwową, wskazując, że obowiązek istniejący po stronie wspólnoty każdorazowo jest prawem określonej jednostki, a obowiązek jednostki - prawem wspólnoty, do której przynależy. Domniemywanie istnienia obowiązków publicznoprawnych jest niedopuszczalne. Treść obowiązku, powiązana każdorazowo z sytuacją prawną, w jakiej znalazła się jednostka, powinna być odczytywana w sposób ścisły i formalny, ze wskazaniem konkretnej normy prawnej, z której wynika dany obowiązek. Następnie prelegent zwrócił uwagę na konieczność prawidłowego wystawienia tytułu wykonawczego oraz wiążące się z tym konsekwencje dla przebiegu postępowania egzekucyjnego. Jako przykład niewłaściwej praktyki w tej mierze referent wskazał na nieprawidłowe określanie podstawy prawnej egzekwowanego obowiązku, która w przypadku wydania przez organ II instancji decyzji utrzymującej w mocy zaskarżoną decyzję organu I instancji wynika z rozstrzygnięcia organu odwoławczego, który orzekając co do istoty sprawy na podstawie art. $138 \S 1$ pkt 1 k.p.a., doszedł do takiego samego przekonania odnośnie do merytorycznej treści decyzji, co organ I instancji.

Druga sesja konferencyjna poświęcona została ochronie sądowej jednostki w administracyjnym postępowaniu egzekucyjnym. W ocenie prof. dr. dr. h.c. Franza-Josepha Peinego (Uniwersytet Viadrina), który przedmiotem refleksji uczynił problematykę sądowoadministracyjnej kontroli administracyjnego postępowania egzekucyjnego w Niemczech, podstawowym przejawem ochrony jednostki w ramach kontroli sprawowanej przez sąd administracyjny jest poddanie każdego z wyróżnionych wcześniej w referacie dr. Axela Schreiera etapów szeroko ujmowanego postępowania egzekucyjnego kontroli sądowej. Referent zwrócił jednocześnie uwagę, że zasady tej kontroli nie budzą obecnie w niemieckim orzecznictwie sądowym zasadniczych wątpliwości. Takie samo stanowisko zaprezentowane zostało przez sędziego Oberverwaltungsgericht w Berlinie Dircka Marescha, który analizując zagadnienie ochrony tymczasowej przed sądem administracyjnym w sprawach z zakresu egzekucji administracyjnej, zauważył, że w postępowaniu tymczasowym jego stronom przysługują takie same środki prawne, jak w postępowaniu prowadzonym w trybie zwykłym.

Z kolei referat sędziego NSA Mieczysława Markowskiego poświęcony został sądowoadministracyjnej kontroli orzeczeń wydawanych w rodzimym administracyjnym postępowaniu egzekucyjnym oraz ich znaczeniu dla biegu postępowania egzekucyjnego. Prelegent, zwracając uwage na samo pojęcie wykonalności aktu administracyjnego, wskazał, że wiąże się ono z możliwością dokonania określonej zmiany w sytuacji prawnej oraz faktycznej podmiotu zobowiązanego przy użyciu ustanowionych przez prawodawcę środków egzekucyjnych. Przedmiotem skargi do sądu administracyjnego są w tym zakresie zapadające w postępowaniu egzekucyjnym postanowienia organów nadzoru rozstrzygające zażalenia na postanowienia organów egzekucyjnych I instancji. Następnie prelegent poddał analizie obecny stan prawny dotyczący wszczęcia postępowania sądowoadministracyjnego (w tym zakres kognicji tego sądu ze szczególnym uwzględnieniem art. $3 \S 2$ pkt 3 p.p.s.a. ${ }^{5}$ oraz trybu wnoszenia skargi do tego sądu).

Ostatni referat poświęcony został analizie dogmatycznoprawnej powództwa o zwolnienie rzeczy spod egzekucji administracyjnej. Doktor hab. Paweł Grzegorczyk (UAM, członek Biura Studiów i Analiz SN), zwrócił uwagę na trudności, jakie wiążą się ze stosowaniem art. 842 k.p.c. ${ }^{6}$ w administracyjnym postępowaniu egzekucyjnym, wskazując na odmienny charakter czynności egzekucyjnej polegającej na zajęciu ruchomości w k.p.c. oraz w u.p.e.a. O ile w egzekucyjnym postępowaniu cywilnym zajęcie ruchomości bazuje na formalnym domniemaniu prawa własności ruchomości dłużnika będących w jego władaniu bądź we władaniu samego wierzyciela, który do nich skierował egzekucję, o tyle z wykładni art. $97 \S$ 1-2 u.p.e.a. nie można wyprowadzić tego

${ }^{5}$ Ustawa z 30 sierpnia 2002 r. - Prawo o postępowaniu przed sądami administracyjnymi, t.jedn.: Dz. U. 2012, poz. 270.

${ }^{6}$ Ustawa z 17 listopada 1964 r. - Kodeks postępowania cywilnego, Dz. U. 1964, Nr 43, poz. 296 ze zm. 
domniemania. Z tego względu art. 842 k.p.c. - w ocenie prelegenta - w odniesieniu do postępowania egzekucyjnego w administracji powinien być traktowany jako szczególny środek prawny służący weryfikacji działania organu administracji publicznej, a nie jako sposób obrony osób trzecich, których prawa zostały naruszone mimo prowadzenia egzekucji zgodnie z przepisami.

Konferencje zakończyły podziękowania prowadzących obrady prof. dr hab. Andrzeja Skoczylasa oraz Prezesa WSA w Poznaniu Jerzego Stankowskiego, skierowane do prelegentów oraz przybyłych gości za liczny i owocny udział w obradach.

Wojciech Piatek wojtekp@amu.edu.pl 
Copyright of Journal of Law, Economics and Sociology is the property of Faculty of Law and Administration of Adam Mickiewicz University in Poznan and its content may not be copied or emailed to multiple sites or posted to a listserv without the copyright holder's express written permission. However, users may print, download, or email articles for individual use.

Właścicielem praw autorskich do „Ruchu Prawniczego, Ekonomicznego i Socjologicznego” jest Wydział Prawa i Administracji Uniwersytetu im. Adama Mickiewicza w Poznaniu. Zawartość czasopisma nie może być kopiowana, przesyłana do innych stron internetowych bądź zamieszczana na blogach bez pisemnej zgody wydawcy. Niemniej artykuły można drukować, kopiować lub przesyłać w formie elektronicznej na własny użytek. 